同時性回腸・盲腸重複癌の 1 例

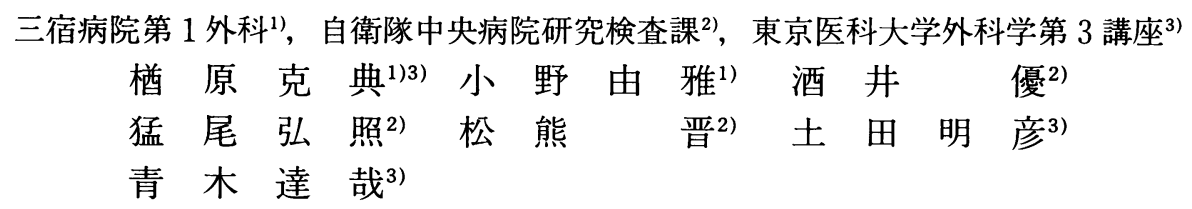

\title{
A Surgical Case of Synchronous Double Cancer Involving the Ileum and Cecum
}

\author{
Katsunori NARAHARA ${ }^{13)}$, Yoshimasa $\mathrm{ONO}^{1)}$, Yuu SAKAI ${ }^{2)}$, \\ Hiroaki TAKEO ${ }^{2)}$, Susumu MATSUKUMA ${ }^{2)}$, Akihiko TSUCHIDA ${ }^{3)}$ \\ and Tatsuya $\mathrm{AOKI}^{3)}$ \\ ${ }^{1)}$ First Department of Surgery, Misyuku Hospital \\ ${ }^{2)}$ Department of Pathology, Japan Self Defense Forces Central Hospital \\ 3) Third Department of Surgery, Tokyo Medical University
}

原発性小腸癌は, 比較的稀な疾患で, 術前診断が困難なことが多い。今回, 盲腸癌の術中に偶然小腸癌を認め, 重複癌と診断。術後 1 年で卯巣・膀胱に転移を認めた症例を経験したので若干の文献的考察を加之報告する。症 例は61歳, 女性。入院時貧血, 腫瘍マ一カー上昇を認めた。盲腸癌の診断で回盲部切除を予定した。術中, 回腸 末端に腫瘍性病変を認め, 回腸も含め切除した。病理診断は盲腸と回腸の重複癌であった。1 年後腫瘍マーカー の上昇, CT上骨盤内腫瘍を認め精査を行った。確定診断目的にて2003年 5 月第 2 回手術を施行, 骨盤内腫瘍は右 卵巣であり, 膀胱漿膜面にも腫瘍を認めた。卵巣腫瘍・膀胱腫瘍は転移性で, 盲腸癌か小腸癌か, 原発巣判定は 困難であった。2004年 4 月現在，外来通院中である。

索引用語：重複癌 (double cancer), 小腸癌 (small intestinal cancer), 大腸癌 (large intestinal cancer)

\section{緒言}

大腸癌と小腸癌の重複は稀な病態であり, 小腸 癌は術前診断も困難なことが多い。最近われわれ は盲腸癌の手術中に偶然小腸癌を認め重複癌と診 断して，手術を施行し，術後 1 年で卵巣・膀胱に 転移を認めた症例を経験したので若干の文献的考 察を加え報告する。

\section{症例}

患 者：61歳，女性。

主 訴: 腹部膨満感, 労作時息切れ, 腹痛。
家族歴：特記すべきことなし。

既往歴：特記すべきことなし。

入院時身体所見：身長 $152 \mathrm{~cm}$, 体重 $47 \mathrm{~kg}$, 体温 $36.3^{\circ} \mathrm{C}$, 血圧 $120 / 70 \mathrm{mmHg}$, 右下腹部に $4 \mathrm{~cm}$ 大, 弾性硬の可動性がわずかに制限された腫瘤を触知 した。

現病歴：2002年 3 月 13 日腹部膨満感, 労作時息 切れ，腹痛にて近医受診。便潜血陽性と貧血を認 め当院紹介入院となった。

入院時検查所見 : 赤血球数 $338 \times 10^{4} / \mu \mathrm{l}$, へモグ ロビン $5.0 \mathrm{~g} / \mathrm{dl}$ と貧血, 総蛋白 $6.3 \mathrm{~g} / \mathrm{dl}$, アルブミン $3.9 \mathrm{~g} / \mathrm{dl}$ と軽度の低栄養を認めた。腫瘍マーカーは 
日本外科系連合学会誌 第 29 巻 6 号

Table 1 Laboratory date on admission

\begin{tabular}{|c|c|c|c|c|c|}
\hline RBC & $338 \times 10^{4} / \mu 1$ & $(380-480)$ & Total cholesterol & $176 \mathrm{mg} / \mathrm{dl}$ & $(120-220)$ \\
\hline Hemoglobin & $5.0 \mathrm{~g} / \mathrm{dl}$ & $(11-15)$ & CK & $241 \mathrm{~J} / 1$ & $(24-120)$ \\
\hline WBC & $7,500 / \mu 1$ & $(4000-9000)$ & BUN & $15.5 \mathrm{mg} / \mathrm{dl}$ & $(8-20)$ \\
\hline PLT & $40.5 \times 10^{4} / \mu 1$ & $(12-35)$ & Creatinine & $0.6 \mathrm{mg} / \mathrm{dl}$ & $(0.7-1.3)$ \\
\hline CRP & $0.8 \mathrm{mg} / \mathrm{dl}$ & $(<0.4)$ & $\mathrm{Na}$ & $141 \mathrm{mEq} / \mathrm{I}$ & $(135-145)$ \\
\hline GOT & $8 \mathrm{U} / 1$ & $(<38)$ & $\mathrm{K}$ & $4.2 \mathrm{mEq} / \mathrm{I}$ & $(3.5-4.9)$ \\
\hline GPT & $6 \mathrm{U} / 1$ & $(<25)$ & $\mathrm{Cl}$ & $108 \mathrm{mEq} / \mathrm{I}$ & $(96-106)$ \\
\hline $\mathrm{LDH}$ & $156 \mathrm{IU} / \mathrm{I}$ & $(<300)$ & $\mathrm{Fe}$ & $15 \mu \mathrm{g} / \mathrm{dl}$ & $(50-120)$ \\
\hline ALP & $149 \mathrm{IU} / \mathrm{I}$ & $(65-215)$ & CEA & $12.0 \mathrm{ng} / \mathrm{ml}$ & $(<5)$ \\
\hline$r$ GTP & $5 \mathrm{IU} / \mathrm{I}$ & $(<20)$ & CA $19-9$ & $40.1 \mathrm{U} / \mathrm{ml}$ & $(<37)$ \\
\hline Cholinesterase & $202 \mathrm{IU} / \mathrm{I}$ & $(200-400)$ & HBs antigen & $(-)$ & \\
\hline Total Bilirubin & $0.2 \mathrm{mg} / \mathrm{dl}$ & $(<1)$ & HCV antibody & $(-)$ & \\
\hline Amylase & $79 \mathrm{lU} / 1$ & $(<200)$ & HIV & $(-)$ & \\
\hline Blood sugar & $101 \mathrm{~g} / \mathrm{dl}$ & $(70-101)$ & TPHA & $(-)$ & \\
\hline Total protein & $6.3 \mathrm{~g} / \mathrm{dl}$ & $(6.8-8.2)$ & RPR & $(-)$ & \\
\hline Albumin & $3.9 \mathrm{~g} / \mathrm{dl}$ & $(4-5)$ & & & \\
\hline
\end{tabular}

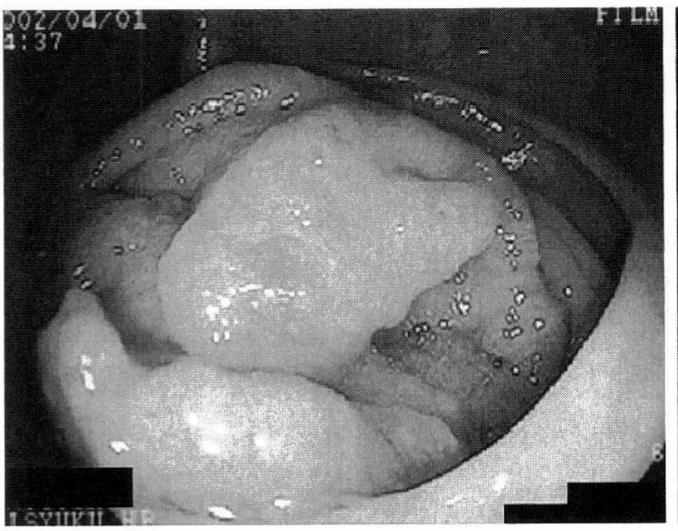

A

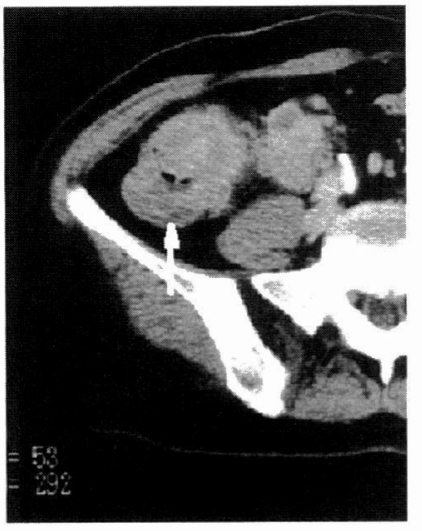

B

Fig. 1A Endoscopic view of the lower digestive tract showed an irregular protrusion at the ileocecal junction and marked stenosis.

B Abdominal computed tomography (CT) scan showed thickening of the caecum wall and disorder of the surrounding fatty tissue. No lymph node swelling was observed within the range of the scan.

CEA $12.0 \mathrm{ng} / \mathrm{ml}$, CA19-9 40.1U/ml と上昇。感染 症などその他異常は認めなかった（Table 1)。

注腸造影検査所見：盲腸に $7 \mathrm{~cm}$ 大の潰瘍を伴 j隆起性病変を認め, 全周性の狭窄を示し, 病変 は明瞭な周提を伴っていた。

大腸内視鏡所見：盲腸に不整の隆起を認め狭窄 が著明であった。生検で腺癌と診断した（Fig. 1A)。また, 肛門より $60 \mathrm{~cm}$ の横行結腸に $5 \mathrm{~mm}$ 大の ポリープを認めた。生検で腺腫と診断した。

CT検査所見：盲腸壁の肥厚々周囲脂肪組織の 乱れがあり，壁の造影効果を認め盲腸癌を疑った。 撮影範囲内で, リンパ節の腫大を認めなかった

(Fig. 1B)。

以上より盲腸癌の診断にて 2002 年 4 月 9 日, 回
盲部切除を予定した。

初回手術所見：盲腸腫瘍とは別に回腸末端に2 cm大の腫瘍性病変を認めた。これを含め切除を行 った。明らかなリンパ節の腫大などは認めなかっ た。

初回手術時切除標本所見：盲腸に $5.5 \times 5 \mathrm{~cm}$ の 2 型の腫瘍を認め, バウヒン弁より口側 $7 \mathrm{~cm}$ の回 腸に $2 \times 1.5 \mathrm{~cm} の 2$ 型の腫瘍を認めた。 2 つの腫 瘍は明らかに離れていた。

初回手術時病理組織所見：盲腸腫瘍は円柱状の 癌細胞が篩状を呈しつつ浸潤増殖する中分化から 高分化腺癌の像で一部粘液の逸脱する像がみられ た。回腸腫瘍は円柱状の癌細胞の乳頭状から絨毛 状の浸潤増殖からなり杯細胞の混在が目立った。 

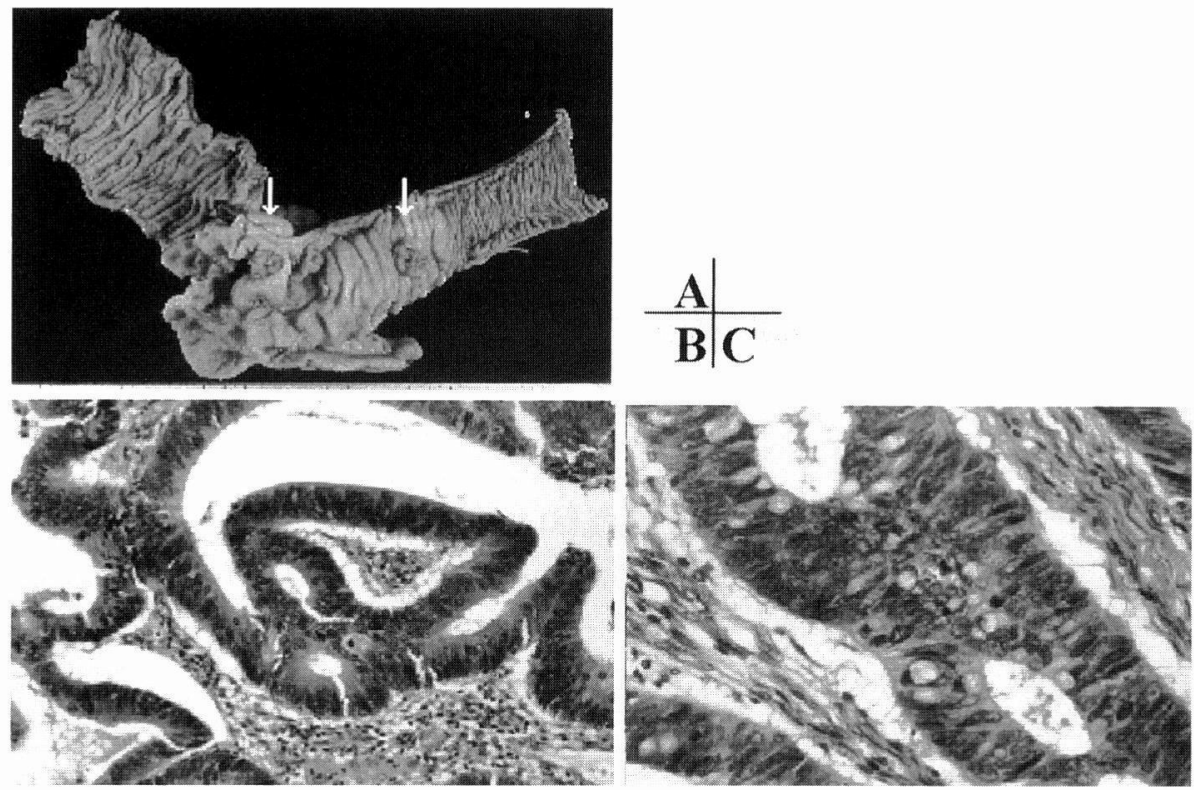

Fig. 2 Pathological findings

A Photomacrograph of the resected specimen: Anatomically, caecum tumor and ileum tumor are clearly separated.

B Microscopic finding of the caecum cancer: type 2, $5.5 \times 5 \mathrm{~cm}$, moderately differentiated adenocarcinoma [se, ly2, v3, aw (-), ow (-), ew(-)]

(HE staining $\times 20)$.

C Microscopic finding of the ileum cancer: type 2, $2.1 \times 1.7 \mathrm{~cm}$, moderately differentiated adenocarcinoma [se, ly $2, \mathrm{v} 2$, aw $(-)$, ow $(-)$, ew(-)]

( $\mathrm{HE}$ staining $\times 40$ ).

The cell morphology of the ileal cancer differed slightly from that of the caecal cancer. For instance, the presence of goblet cells was conspicuous. In addition, a mucous membrane focus had formed. It was seemed to be primary ileal cancer.

盲腸癌とやや細胞形態が異なっていた。また，回 腸腫瘍周囲リンパ節に転移を認めた。

盲腸癌 [ 2 型, se, P0, H0, N1, ly2, v2, aw $(-)$, ow $(-)$, ew $(-)]$, 回腸癌 [ 2 型, se, P0, $\mathrm{H} 0, \mathrm{~N}(+)$, ly2, v2, aw $(-)$, ow $(-)$, ew $(-)]$

(Fig. 2)。

盲腸・回腸の各腫瘍は悪性像を呈し，腫瘍間に $7 \mathrm{~cm}$ 以上の正常粘膜を持ち, 細胞形態が異なるこ とから互いに転移ではないと考えられた。以上よ ク, Warren ${ }^{122)}$ の重複癌の基準に基づき, 盲腸癌 と小腸癌の同時性重複癌と診断した。大腸癌取扱 い規約上，根治手術を行えたと判断した。

初回術後経過：化学療法 $\left(M M C 8 \mathrm{mg} / \mathrm{m}^{2}\right.$ 静注 で2 回 5 FU 150mg/日, Krestine $3 \mathrm{~g} /$ 日, シメチ
ジン $400 \mathrm{mg}$ / 日内服）を実施後，術後14日目に退院 した。以後外来で化学療法(内服の継続ならびに, $\mathrm{MMC} 8 \mathrm{mg} / \mathrm{m}^{2}$ 静注を 5 月， 7 月， 9 月の 3 回実 施）を行った。

CEAの上昇に続き, 術後 1 年時のCTにて骨盤 内に腫㾇を認めた。精查目的にて，2003年 4 月 14 日に入院となった。

第 2 回手術前検査所見：ALP $341 \mathrm{IU} / 1$ と軽度上 昇, 総蛋白 $6.7 \mathrm{~g} / \mathrm{dl}$ と軽度低栄養を認めた。腫瘍マ ーカーはCEA 11.2ng/ml, CA72-43.4U/ml, と 上昇していた (Table 2)。

大腸内視鏡所見 : 大腸回腸吻合部まで異常所見 は認めなかった。

第 2 回手術前 CT検査所見：骨盤内腫瘍が仙椎 
日本外科系連合学会誌 第 29 卷 6 号

Table 2 Laboratory date before the 2nd operation

\begin{tabular}{|c|c|c|c|c|c|}
\hline RBC & $374 \times 10^{4} / \mu 1$ & $(380-480)$ & $\mathrm{CK}$ & $42 \mathrm{IU} / 1$ & $(24-120)$ \\
\hline Hemoglobin & $12.5 \mathrm{~g} / \mathrm{dl}$ & $(11-15)$ & BUN & $15.1 \mathrm{mg} / \mathrm{d}$ & $(8-20)$ \\
\hline WBC & $5,100 / \mu 1$ & $(4000-9000)$ & Creatinine & $0.7 \mathrm{mg} / \mathrm{dl}$ & $(0.7-1.3)$ \\
\hline PLT & $17.5 \times 10^{4} / \mu \mathrm{I}$ & $(12-35)$ & $\mathrm{Na}$ & $139 \mathrm{mEq} / \mathrm{l}$ & $(135-145)$ \\
\hline CRP & $<0.1 \mathrm{mg} / \mathrm{dl}$ & $(<0.4)$ & $\mathrm{K}$ & $4.4 \mathrm{mEq} / \mathrm{l}$ & $(3.5-4.9)$ \\
\hline GOT & $18 \mathrm{U} / \mathrm{I}$ & $(<38)$ & $\mathrm{Cl}$ & $106 \mathrm{mEq} / \mathrm{I}$ & $(96-106)$ \\
\hline GPT & $23 \mathrm{U} / \mathrm{I}$ & $(<44)$ & CEA & $11.2 \mathrm{ng} / \mathrm{ml}$ & $(<5)$ \\
\hline $\mathrm{LDH}$ & $140 \mathrm{IU} / \mathrm{I}$ & $(<211)$ & CA19-9 & $33.3 \mathrm{U} / \mathrm{ml}$ & $(<37)$ \\
\hline ALP & $341 \mathrm{JU} / 1$ & $(104-338)$ & & & \\
\hline$r$ GTP & $22 \mathrm{JU} / 1$ & $(<30)$ & & & \\
\hline Cholinesterase & $244 \mathrm{IU} / 1$ & $(200-400)$ & & & \\
\hline Total bilirubin & $0.6 \mathrm{mg} / \mathrm{dl}$ & $(<1)$ & & & \\
\hline Blood sugar & $92 \mathrm{~g} / \mathrm{dl}$ & $(70-101)$ & & & \\
\hline Total protein & $6.7 \mathrm{~g} / \mathrm{dl}$ & $(6.8-8.2)$ & & & \\
\hline
\end{tabular}

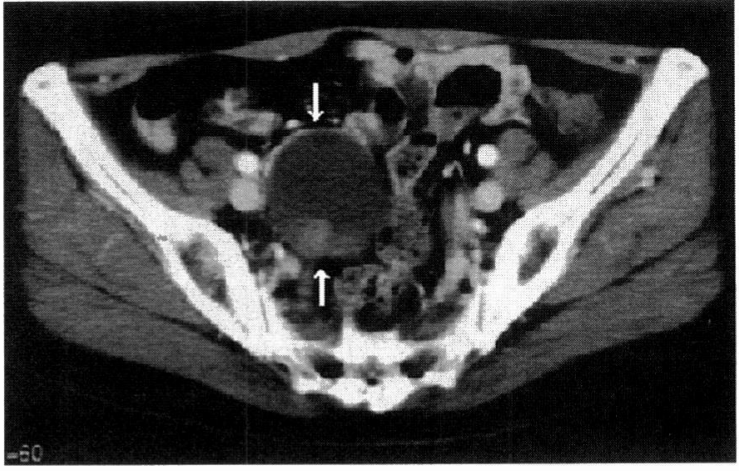

A

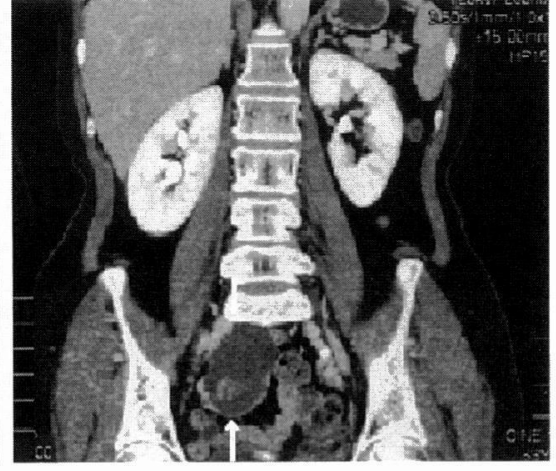

B

Fig. 3 CT scan before the 2 nd operation showed a pelvic tumor present at the level of the sacral vertebra. It was located cephaladly relative to the normal position of the ovary.

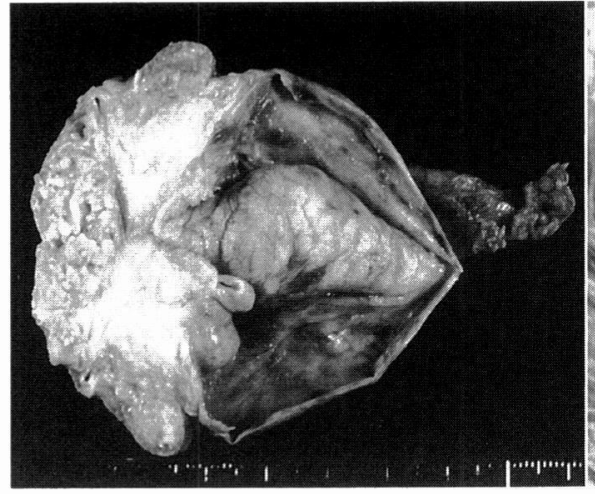

A

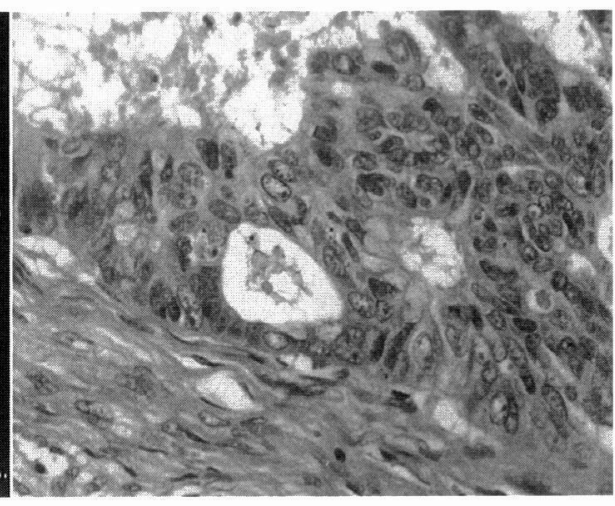

B

Fig. 4A Photomacrograph of the right ovary (gross section).

$B$ Microscopic findings of the right ovary : Metastaic adenocarcinoma (HE staining. $X$ 40).

The right ovary tumor possessed the histologiclly similar characters of cecum cancer and ileum cancer. 
同時性回腸·盲腸重複癌の 1 例

Table 3 Cases of double cancer (large intestine and small intestine)

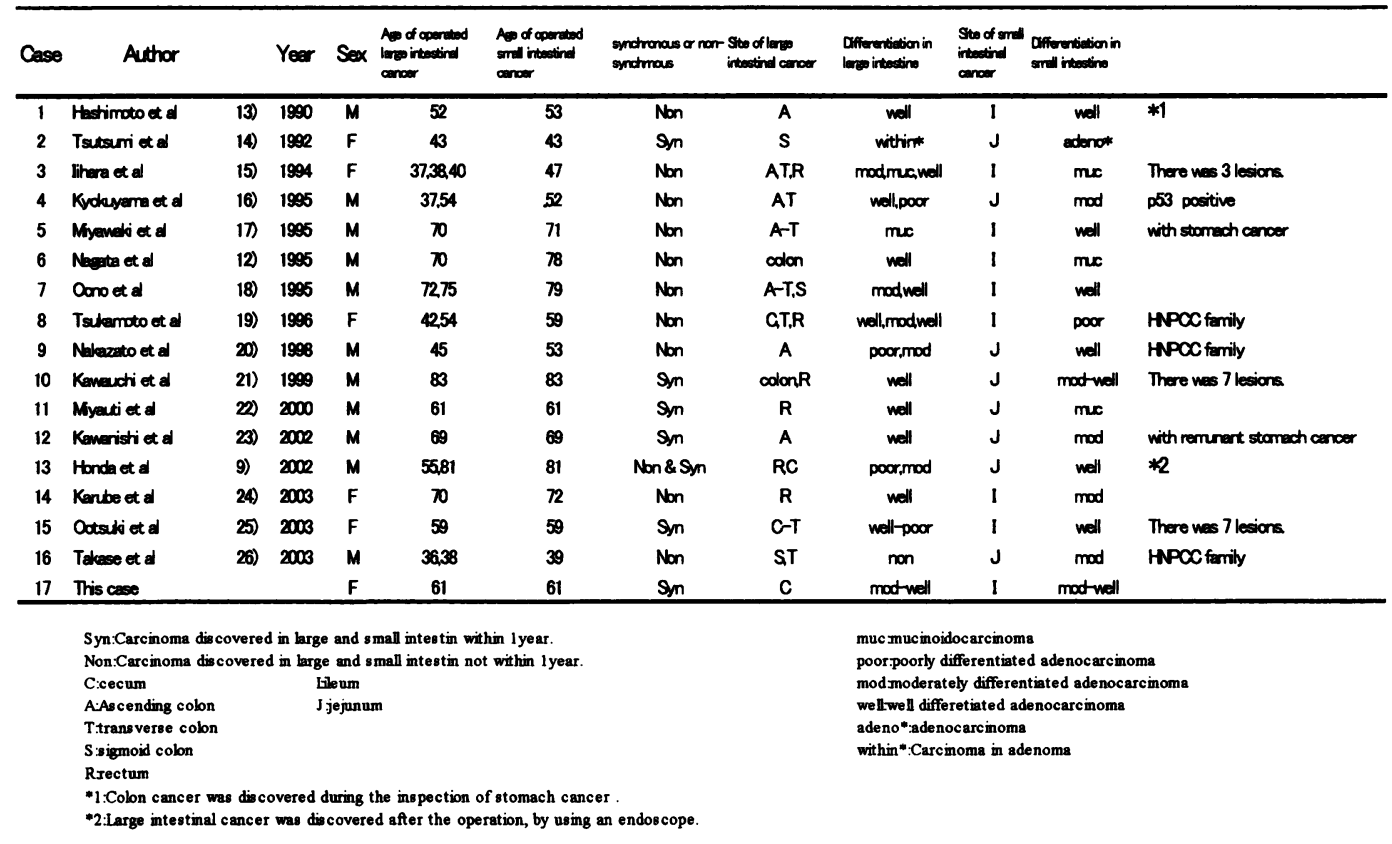

上縁レベルに存在した。腫瘍は, 通常卵巣が存在 する位置よりも頭側に存在した（Fig. 3)。

シンチグラム所見：ガリウムシンチおよび骨シ ンチとも，異常集積は認めなかった。

さらに婦人科検診を含めた諸精査も行ったが子 宮癌や内膜症は否定的であった。以上より卵巣腫 大またはリンパ節腫大が疑われ，確定診断を目的 に2003年 5 月 14 日，第 2 回手術を施行した。

第 2 回手術所見：骨盤内腫瘍は $7 \mathrm{~cm}$ 大で囊胞 性で右卵巣であった。また, 膀胱壁に腹腔内播種 性転移を疑う， $1 \mathrm{~cm}$ 大の結節を認めた。右卵巣摘 出術と膀胱部分切除術を行った。

第 2 回手術時病理組織所見：右卵巣腫瘍は，異 型核を有する円柱状癌細胞が壊死を伴いつつ増殖 像を認めた転移性腺癌であった。盲腸癌と回腸癌 のいずれとも類似した像で原発巣確定は困難であ った。膀胱も, 転移性腺癌で, 卵巣癌と同様に原 発巣判定は困難であった。膀胱粘膜・内腔への浸潤 は明らかでなく漿膜面に露出を認めた (Fig. 4)。

第 2 回手術後経過：第 2 回手術後 7 日目に $\mathrm{MMC} 12 \mathrm{mg} / \mathrm{m}^{2}$ 静注し, 術後 8 日目退院となっ た。

退院後外来にて，術後14日目より 5 FU 150mg/
日, Krestine $3 \mathrm{~g} /$ 日, シメチジン $400 \mathrm{mg} /$ 日の内服 を開始した。 $\mathrm{MMC} 6 \mathrm{mg} / \mathrm{m}^{2}$ を 6 月, 7 月の 2 回, $\mathrm{MMC} 4 \mathrm{mg} / \mathrm{m}^{2}$ を 1 カ月ごとに投与した。2004年 4 月現在治療継続中であるが，再発の兆候を認め ていない。

\section{考察}

大腸重複癌の発生頻度は4.4 7.7\%と報告され ている。重複は胃癌が最も多く約 3 分の 1 を占め 次いで子宮癌の頻度が高い。他に乳房，喉頭・咽 頭，肺，肝，尿路系などに重複が多い344)。一方， 原発性小腸覀性腫瘍は全消化管覀性腫瘍の

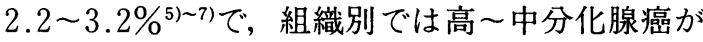
多い。さらに全消化管癌に占める回腸癌の割合は $0.01 \%{ }^{4) 8}$ とされている。以上より, 大腸癌と小腸 癌との重複は稀と考之られる。本症例を含めて調 べた限り (医学中央雑誌で検索), 最近10年で17例

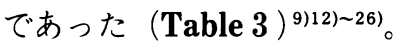

これら17例を検討する。大腸癌 -小腸癌の重複 例は同時性 7 例，異時性11例とやや異時性が多か った。男女比は 11 対 6 と男性に多かったが，同時 性に限ると男女比は 4 対 3 であった。重複例の大 腸癌初発発症年歯は37歳から83歳 (平均56.6歳), 
小腸癌の発症年齢は39歳から83歳（平均62.3歳）, 同時性に限ると43歳から83歳（平均65.2歳）であ った。異時性では小腸癌先行の報告はなかった。 小腸癌の存在部位は空腸 8 例, 回腸 9 例とやや回 腸が多かった。同時性 6 例中 3 例は大腸癌多発例, 1 例は残胃癌も重複した 3 重複癌例であった。異 時性では11例中 6 例は大腸癌多発や多臓器癌重複 例であり，4例は遺伝性が明らかであるなど高リ スク群であった。本症例は家族歴も大腸癌の多発 病変も認めていない点で過去の報告と異なる症例 と考えられた。

大腸癌において, 同時性重複癌が異時性重複癌 よりも予後が悪いとの報告がある ${ }^{9) \sim 11) 。 そ の た め, ~}$ 本症例では後療法として 1 回目の手術後 $\mathrm{MMC}$ 静

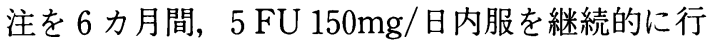
ったが，術後 1 年で卵巣と膀胱に転移を生じた。 $\mathrm{MMC}$ 静注中止後から腫瘍マーカー值が上昇した ため, 腫瘍が増悪したと判断した。そのため， 2 回目の手術後も, $\mathrm{MMC}$ 投与を継続した。 $\mathrm{MMC}$ 静

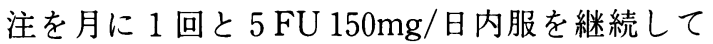
いる。現在のところ再発を認めていない。術後治 療に関しては，17例中記載があるものは異時性 1 例のみであり, その症例も 1 回目の大腸癌手術後 の化学療法であった ${ }^{12)}$ 。重複を確認した後に化学 療法などを実施した報告はなかった。同時性重複 癌を認めた場合, 大腸癌単独, 小腸癌単独の場合 よりも入念な経過観察が必要で後療法を考慮すべ きと考える。

\section{結語}

回腸癌と盲腸癌の同時性重複例を経験した。報 告によると同時性重複癌は異時性重複癌より予後 不良で, 本症例も, 早期に転移をきたした。重複 癌を認めた場合, 大腸癌単独あるいは小腸癌単独 よりも, 後療法を実施し, 入念な術後の経過観察 が必要と考える。

本論文の要旨は, 第65回日本臨床外科学会総会 （2003年11月）において発表した。

\section{参考文献}

1）赤崎兼良, 若狭治穀, 石館卓三：原発性重複癌に ついて。 日臨19：1543-1551，1961
2) Warren S, Gates O: Multiple primary malig. nant tumors. Asurvey of literature and a statistical study. Am J Cancer 16 : 1358-1414, 1932

3）小棚木 均, 吉岡年明, 相沢 修他: 大腸多藏器 重複癌106例の検討. 日本大腸肛.門病会誌 $49 ： 207$ $-212 ; 1996$

4）前田耕太郎, 丸田守人, 内海俊明他：大腸癌にお ける多重癌の臨床。外科 $60 ： 278-282,1998$

5）横山善文，妹尾恭司，片岡洋望他：小腸上皮性腫 瘍（癌・腺腫）。胃と腸 $36 ： 883-890,2001$

6) 日本病理学会編：日本病理剖検輯報。第 41 輯, 平 成10年度剖検例収録, 日本病理剖検輯報刊行会, 東京, 2000, p1104-1108

7) Martin $R$ : Malignant tumors of the small intestine. Surclin North Am $66: 779-785,1986$

8）高橋 孝, 池 秀之, 池田孝明他：腸癌. 日臨41 (春 期臨時增刊号) : 1369-1382，1983

9）本田勇二，河野哲夫，田中暢之他：多発大腸 - 小 腸重複癌の 1 例. 日臨外会誌 $63: 2585-2590,2002$

10）出射秀樹，中本光春，裹川公章他：大腸重複癌の 臨床病理学的検討。日本大腸肘門病会誌 $42 ： 1039$ $-1043,1989$

11）増田英樹, 林 成興, 谷口利尚他：大腸他臓器重 複癌の臨床的検討. 日臨外会誌 $53: 537-542,1992$

12）長田真二, 種村廣巳, 大下祐夫：大腸癌術後 8 年 目にイレウスにて発症した小腸癌の 1 手術例. 癌 の臨41：1113-1117，1995

13）橋本 晃，上田俊二，塚田英昭他：胃 - 大腸 - 小 腸の消化管三重複癌と考之られる 1 例. Gastroenterol Endosc $32: 1551 ， 1990$

14）堤 純, 秋本 博, 堀 訓也他：早期大腸癌を 合併した小腸癌の 1 例. 日消病会誌 $89 ： 883,1992$

15）飯原啓介, 高見元做, 藤本高義他：小腸癌を合併 した異時性大腸多発癌症例。日臨外会誌 55 (増刊 号) : 290, 1994

16）諫山冬実, 坂本一博, 日野眞子他：16年間に大腸 癌を 2 回，小腸癌を 1 回認めた 1 例。順天堂医 $42: 103-106,1996$

17）宮脇貴裕, 雨宮 哲, 岡 昭一他：胃, 小腸, 大 腸の三重複癌の 1 例. 日臨外会誌 56 (増刊号)： 256, 1995

18）大野義一朗, 継 篤, 濱砂一光他：多発大腸癌 に続発した小腸癌の 1 例。日臨外会誌 $56 ： 2503$, 1995 
19）塚本文音，高見元螦，木村正治他：4 世代にわた り大腸癌が多発したHNPCCの 1 家系. 胃と腸 $31: 869-874,1996$

20）中里雄一, 稲坦芳則, 篠田知太朗他：遺伝性非ポ リポーシス大腸癌術後に発症した原発性小腸癌 の 1 例。 日消外会誌 $31 ： 1131-1135 ， 1998$

21）河内保之, 廣田正樹, 金子耕司他：大腸 7 多発癌 と原発性空腸癌を同時に重複した 1 例. 日臨外会 誌60：1956-1959, 1999

22）宮内忠雅, 片桐義文, 味元宏道他：早期大腸癌を 伴った小腸癌の 1 例。岐阜大医紀 $48 ： 32,2000$
23）河西 秀, 田内克典, 湯口 卓他：治癒切除が施 行し之た残胃癌, 空腸癌, 上行結腸癌の同時性三 重複癌の 1 例. 日臨外会誌63(増刊号)：781, 2002

24）軽部秀明，增田英樹，石井敬基他：直腸癌術後に 発症した原発性小腸癌の 1 例. 日本大腸肛門病会 誌56：114-117，2003

25）大柣 将, 岩瀬尚子, 権田 剛他：同時性多発大 腸癌と小腸癌の 1 例。日臨外会誌 $63: 2850,2002$

26）高瀬功三，塚本好彦，湯木 毅他：遺伝性非ポリ ポーシス大腸癌 (HNPCC) 術後に発症した小腸癌 の 1 例。 日消外会誌 $36 ： 977,2003$ 